\title{
INTERNATIONALIZING REVOLUTION: The Nicaraguan Revolution and the World, $1977-1990$
}

his special issue traces its roots to a workshop on the international, transnational
and global dimensions of the Nicaraguan Revolution beld at the London
School of Economics and Political Science (LSE) in May 2019. Convened by Dr. Eline van Ommen and Dr. Tanya Harmer, the editors of this special issue, the workshop was generously funded by the LSE Department of International History and the LSE Latin America and Caribbean Centre. Most of the articles that follow were first presented at this workshop, where a lively exchange took place on the revolution's history and present-day legacies.

Revolutions by their very nature have the potential to reshape and disrupt international affairs. In overthrowing the existing order, they unsettle foreign alignments and raise questions about a country's position in the world. This need not necessarily lead to a radical overhaul of a country's external relations. But just as foreign observers respond and adjust to change, incoming revolutionary regimes face the task of redesigning their country's foreign policy to serve new interests and ideologies. Control over foreign affairs, after all, is fundamentally important as a marker of power and independence to shape a nation. It is no accident that the Platt Amendment put limits on the nascent Cuban Republic's ability to manage its external relations as a means of the United States' retaining control over the island's future. It is also no surprise that counterrevolutionary strategies have aimed to contain new revolutionary states' ability to project their message and influence outside their national borders.

For Latin American revolutionary states during the twentieth century, the question of how to simultaneously assuage US hostility and maintain credit flows and trading opportunities while resisting counterrevolutionary attacks was also of enormous and immediate concern. This in turn led many to use 
foreign policy as an instrument of defense. For Cuban revolutionaries after 1959, promoting revolutionary change abroad in Cuba's image was intended to make the world safer for revolutionary change at home. ${ }^{1}$ By contrast, Chile's democratically elected revolutionary government in the early 1970s sought to neutralize threats abroad and not antagonize potential enemies. In part learning from Cuba's experience, the Chileans thus opted for ideological pluralism and emphasized Chile's exceptional position (rather than its inherent applicability). ${ }^{2}$

Less than a decade later, the triumph of the Nicaraguan Revolution in July 1979 radically altered Nicaragua's foreign policy. In this case, the revolution's leading force, the Frente Sandinista de Liberación Nacional (Sandinista National Liberation Front, FSLN), regarded the reorientation of Nicaragua's foreign policy as an essential component of the change it sought to usher forth. In liberating Nicaragua from the control of Anastasio Somoza Debayle's dictatorship, the FSLN directly challenged Nicaragua's alignment with, and dependency on, the United States. For the revolution to succeed, thrive and survive, they argued, Nicaragua needed to assert a new, independent international position. Henceforth, drawing on both Cuban and Chilean precedents, as well as revolutionary examples from beyond the Americas, the FSLN supported change abroad and employed strategies of ideological pluralism. This involved support for the insurgents in El Salvador, intimate ties with Cuba, and good relations with social democratic governments in Western Europe.

As counterrevolutionary attacks against the revolution grew, however, pragmatism increasingly overrode optimism as the FSLN sought financial assistance and an end to conflict. In this respect, support for revolution abroad ended, while defense through international and transnational engagement became a priority. Dependency on the Soviet bloc was also increasingly a reality. Solidarity groups that had once been supportive in the fight against Somoza were rebooted and mobilized, foreign ministries were lobbied, and negotiators were increasingly listened to. For if the revolution was to endure in what had traditionally been the US sphere of influence, it would need influential allies, funds, and peace.

This special issue examines the international history of the Nicaraguan Revolution. It asks how, why, and with what consequences Nicaragua's revolutionary leadership interacted with the world it encountered, as well as

1. Jorge I. Domínguez, To Make a World Safe for Revolution: Cuba's Foreign Policy. (Cambridge: Harvard University Press, 1989); Jonathan C. Brown, Cuba's Revolutionary World (Cambridge; London: Harvard University Press, 2017); Dirk Kruijt, Cuba and Revolutionary Latin America: An Oral History (London: Zed Books, 2017).

2. Tanya Harmer, Allende's Chile and the Inter-American Cold War (Chapel Hill: University of North Carolina Press, 2011). 
how its foreign policy evolved overtime. It also explores how non-Nicaraguans engaged with the revolution. The Nicaraguan Revolution's timing and character reverberated throughout the Americas and the wider world, suggesting the advent of a new revolutionary moment in global politics. From Grenada to Iran and Angola to Afghanistan, radical change appeared to be unsettling global politics, indicating that the Cold War balance of power was shifting away from the United States and its allies. By the early 1980s, Nicaragua thus became a central focus of US efforts to fight back in what became a major new Cold War offensive. Led by Ronald Reagan's administration, millions of dollars and political capital were expended on trying to reverse the FSLN's victory. In the battle for Nicaragua that followed, military conflict led by the Contras-counterrevolutionary insurgents-was only one of a number of instruments employed. As the articles in this special issue show, perceptions, public opinion, and questions of legitimacy mattered. Diplomacy and transnational relations were central to how the struggle to determine Nicaragua's future ensued.

Four decades after the Sandinista triumph, chronological distance means that a new generation of scholars has taken on the task of understanding the Nicaraguan Revolution's international significance, freed from the constraints of refighting the Cold War's battles. To date, scholarly debates about the Sandinista period, more often than not, have tended to be more concerned with the question of the (il)legitimacy of US foreign policy and Cold War interventions than with the complexities, nuances, and global reverberations of the FSLN's revolutionary project. ${ }^{3}$ Limited access to archival sources both within and outside Nicaragua also constrained historians' ability to trace the international history of the revolution. To an extent, the collapse of the Soviet bloc allowed some to begin exploring relations with Nicaragua. ${ }^{4}$ Inspired by

3. Walter LaFeber, Inevitable Revolutions: The United States in Central America, 2nd ed. (New York: W. W. Norton, 1993); William M. LeoGrande, Our Own Backyard: The United States in Central America, 1977-1992 (Chapel Hill: University of North Carolina Press, 1998); Robert Kagan, A Twilight Struggle: American Power and Nicaragua, 19771990 (New York: Free Press, 1996); Robert A. Pastor, Not Condemned to Repetition: The United States and Nicaragua, 2nd. ed., (Boulder, CO: Westview Press, 2002); William Michael Schmidli, “The Most Sophisticated Intervention We Have Seen': The Carter Administration and the Nicaraguan Crisis, 1978-1979," Diplomacy \& Statecraft 23:1 (2012): 66-86; David Lee, "De-centering Managua: Post-Earthquake Reconstruction and Revolution in Nicaragua," Urban History 42:4 (2015): 663-685. Some exceptions to this US-centric perspective published in recent years include Mario Vázquez Olivera and Fabián Campos Hernández, eds., México ante el conflicto centroamericano. Testimonio de una época (Mexico City: Universidad Nacional Autónoma de México, 2016); and Gerardo Sánchez Nateras, "The Sandinista Revolution and the Limits of the Cold War in Latin America: The Dilemma of Non-Intervention during the Nicaraguan Crisis, 1977-78," Cold War History 18:2 (April 1, 2018): 111-130.

4. See for example, Klaus Storkmann, "East German Military Aid to the Sandinista Government of Nicaragua, 1979-1990," Journal of Cold War Studies 16:2 (April 1, 2014): 56-76; María Dolores Ferrero Blanco, "Daniel Ortega y Mijail Gorbachov. Nicaragua y la URSS en los últimos años de la guerra fría (1985-1990)," Hispania Nova. Revista de Historia Contemporánea 13 (2015): 26-53. Still among the best histories of Cuban and Soviet relations with Nicaragua that do not draw on declassified sources are Gary Prevost, "Cuba and Nicaragua: A Special Relationship?" Latin American Perspectives 17:3 (1990): 120-137; and Danuta Paszyn, The Soviet Attitude to Political and Social 
the turn to transnational history and the plethora of sources produced by solidarity work, other scholars have ventured to explore the FSLN's wider global history by focusing on transnational activism and networks. ${ }^{5}$ In doing so, they have upended the tendency for transnational histories to supplement an existing diplomatic narrative and have done a lot to map out a space for more inclusive international histories. But, until relatively recently, state-level and foreign ministry perspectives were limited by the dearth of archival material to work with.

Historians' ability to map out a fuller international history in conversation with transnational approaches - or, more significantly, to integrate both approaches as many of the articles that follow do-has therefore been transformed by new declassifications in the archives of Latin America, Europe, and, to a greater degree than before, the United States. Notably, Cuba's foreign ministry has begun to release its archival collections. Crucially, historians have also begun gaining access to archives and private collections in Nicaragua that have allowed them to explore the FSLN's international aims in a way they had not previously been able to. And, in all respects, these archival openings have been complemented by a growing number of published memoirs and the willingness of protagonists to offer oral histories. ${ }^{6}$

Access to these sources has stimulated a new wave of research on the Nicaraguan Revolution. Where once historians struggled to find material to work with, they are now juggling information from different archives and collections simultaneously. Reflective of this new international history of the Nicaraguan

Change in Central America, 1979-90: Case-Studies on Nicaragua, El Salvador and Guatemala (Basingstoke: Macmillan, 2000).

5. José Manuel Ágreda Portero and Christian Helm, Dossier "Redes transnacionales de solidaridad política entre Europa y Centroamérica durante las décadas de los setenta y ochenta," Naveg@mérica. Revista electrónica editada por la Asociación Española de Americanistas 17 (2016); Laurin Blecha, “iVietnam en América Latina!” Naveg@mérica 17 (2016); Kim Christiaens, "Between Diplomacy and Solidarity: Western European Support Networks for Sandinista Nicaragua," European Review of History: Revue Européenne d'bistoire 21:4 (2014): 617-34; Christian Helm, "Booming Solidarity: Sandinista Nicaragua and the West German Solidarity Movement in the 1980s," European Review of History/ Revue Européenne d'histoire 21:4 (2014): 597-615; Fernando Camacho Padilla and Laura Ramírez Palacio, "Las imágenes de las guerrillas centroamericanas en las redes de la solidaridad internacional de Suecia," Naveg@mérica 17 (2016); Roger C. Peace, A Call to Conscience: The Anti-Contra War Campaign, Culture, Politics, and the Cold War (Amherst; Boston: University of Massachusetts Press, 2012); Eline van Ommen, "La Revolución Sandinista en los Países Bajos,” Naveg@mérica 17 (2016); José Manuel Ágreda Portero and Friederike Apelt, Dossier, "Las relaciones transnacionales de solidaridad con los movimientos revolucionarios latinoamericanos durante la guerra fría," Secuencia: Revista de Historia y Ciencias Sociales 18 (2020).

6. Tomás Borge, La paciente impaciencia (Havana: Casa de las Américas, 1989); Arturo Cruz, Memoirs of a Counter-Revolutionary: Life With the Contras, the Sandinistas, and the CLA (New York: Doubleday, 1989); Sergio Ramírez, Adiós muchachos: una memoria de la Revolución Sandinista (Madrid: Editorial Aguilar, 1999); Gioconda Belli, El país bajo mi piel: memorias de amor y guerra (Barcelona: Plaza y Janés, 2001); Ernesto Cardenal, La revolución perdida (Managua: Anamá Ediciones Centroamericanas, 2004); Fernando Cardenal, Junto a mi pueblo, con su revolución: memorias (Madrid: Editorial Trotta, 2009); Humberto Ortega Saavedra, La odisea por Nicaragua (Managua: Lea Grupo Editorial, 2013); Roxanne Dunbar-Ortiz, Blood on the Border: A Memoir of the Contra War (Norman: University of Oklahoma Press, 2016). 
Revolution, the four articles that follow draw on the archives of 14 countries, plus oral histories and multiple published and online sources. As the vanguard of a new generation of historians of Nicaragua, authors of these articles blend transnational and diplomatic approaches, presenting a new international history that reflects the many overlapping ways that relations between states and peoples took place. Not only does this blending reflect the dexterous and ambitious foreign policy the FSLN pursued at multiple levels (and the way non-Nicaraguans responded to the revolution) but it also offers an important intervention when it comes to thinking about the international history of the Global South during the Cold War more generally.

In bringing diplomatic and state-level perspectives into the study of Nicaragua's revolution, these authors challenge a historiographical pattern wherein the Global South does solidarity and transnational activism while the Global North-and great powers-do diplomacy and statecraft. The point is obvious but deserves underlining: states of different ideological persuasions on all sides of the globe have done both.

Historians examining the Nicaraguan Revolution today are influenced by the significant burgeoning of scholarship on the Cold War in Latin America over the last decade. ${ }^{7}$ This means bringing Latin American actors far more centrally into the picture, questioning what had been an exclusive focus on US intervention, thinking about the broader regional and international contexts in which change occurred, and understanding the periods between isolated moments of crisis. It also means that diplomatic historians have engaged meaningfully with historians of culture, society, and economics. Significantly, it has led scholars to move away from simplistic binary left-right interpretations of the past to explore the range of different positions involved in fighting the Cold War. The tendency to write history as a zero-sum game in which one side's wrongdoing equates to another side's automatic exoneration is increasingly being questioned. Greater attention to the everyday experience of ideologically charged conflict has meanwhile led historians to grapple with how individuals and communities affected such conflicts, and were affected by them. This attention pertains not only to grassroots perspectives but can also, as Emily Snyder's article in this issue demonstrates, help us understand the

7. Hal Brands, Latin America's Cold War (Cambridge: Harvard University Press, 2010); Greg Grandin and Gilbert M. Joseph, A Century of Revolution: Insurgent and Counterinsurgent Violence during Latin America's Long Cold War (Durham: Duke University Press, 2010); Gilbert M. Joseph and Daniela Spenser, eds., In from the Cold: Latin America's New Encounter with the Cold War (Durham: Duke University Press, 2008); Gilbert M. Joseph, "Border Crossings and the Remaking of Latin American Cold War Studies," Cold War History 19:1 (2019): 141-170; Vanni Pettinà, Historia minima de la Guerra Fría en América Latina (Mexico City: El Colegio de México, 2018). 
broader repertoires, mechanics, and practices involved in processes of revolutionary change and ideological contestation.

With this context in mind, the following articles make three broad thematic contributions to the historiography of the Nicaraguan Revolution, the Cold War in Latin America, and the history of revolution in the Americas. First, articles by Emily Snyder, Eline van Ommen, and Mateo Jarquín provide new insight into how a small revolutionary state in Latin America sought to juggle its aims and needs in the shadow of US power. They show how the FSLN conceptualized foreign affairs, how and why it sought to interact with the Cold War system beyond its borders in the way it did, what support it was able to draw on, and with what consequences. Through an examination of Cuba's "deep involvement" in Nicaragua, Snyder provides an unprecedented window onto the FSLN's institution-building and the challenges involved. She reveals the extent to which Cuba served as a model for the new Nicaraguan state and the different levels of influence it had in training diplomats, providing technical assistance, and advising on cultural programs. She also sheds light on problems and tensions that ensued as a result of this cooperation. The day-to-day experiences of individuals involved in cultural diplomacy and international affairs expose the complex realities of managing revolutionary diplomacy that move us beyond romanticized solidarity and collaboration.

If Snyder's article provides a picture of the trials and tribulations of a revolutionary state's foreign policy in the making, Van Ommen and Jarquín are in agreement that pragmatism and adaptation won out as crucial features in how the FSLN's foreign policy evolved. As the two authors posit, this was calculated as a means to an end rather than an end in itself, and revealed the perceived importance of presentation and public opinion in Nicaragua's revolutionary diplomacy. As Van Ommen shows, the FSLN's leaders preemptively strove to convince the international community of the "moderate nature" of the revolution. They did so for both offensive and defensive reasons.

The moderate posture was designed to buy the FSLN time, but also, significantly, to consolidate its power and overcome opponents. When it came to the Contra war, for example, Jarquín notes that like US policymakers, the FSLN preferred the idea of military victory to negotiation and saw peace talks merely as a means of constraining the enemy. Nevertheless, in charting the FLSN's efforts to break free of the Monroe Doctrine-and thus the potential for US power in determining Nicaragua's future-Van Ommen shows how the FSLN's tactical calculations changed over the course of the 1980s as the economy worsened and the hope of revolutionary change abroad diminished. In appealing to Western Europe as a counterweight to the United States, the FSLN 
increasingly accepted the "necessary inconvenience" of international negotiations and involvement, ultimately agreeing to major concessions to secure peace-not to push the revolution forward, but to help it survive. Meanwhile, the lens international history provides is not related simply to Nicaragua's position on a world stage, but also to the revolution's trajectory at home. Both Snyder and Van Ommen, in particular, show how the FSLN's foreign relations directly related to domestic pressure and fortunes, serving as a lens through which to examine the course of events inside Nicaragua as well as beyond.

In regard to the ideological character of the Nicaraguan Revolution, the authors of the special issue use different terminologies but are largely in agreement with one another. The FSLN leadership might have argued publicly that sandinismo transcended the Cold War, but there is little doubt that it considered socialist Cuba to be its closest ideological ally. Jarquín, for example, discusses the "Marxist orientation" of the FSLN's collective leadership, as well as Nicaragua's ties to the socialist bloc. Van Ommen makes a similar point, demonstrating-in spite of its outreach to Western Europe - that the FSLN was inspired by Cuba and saw the Soviet Union as an "ally in the global struggle against imperialism." Snyder focuses on the practical implications of the Sandinistas' admiration for Cuba's political system, showing how the FSLN used "similar strategies to consolidate their political control.”

To be sure, the authors refer in these regards specifically to the FSLN leadership. Throughout the 1980s, grassroots visions of what the revolution should look like and how it should unfold were remarkably diverse and often in contradiction with the top-down approach that the collective leadership had in mind. In spite of the Sandinistas' close connections to Cuba, one of the most obvious characteristics of Nicaragua's revolutionary process was its plurality, which initially brought together a wide range of ideological strands, varying from social democracy to liberation theology to Marxism-Leninism. Prior to Somoza's fall, even the FSLN leaders were divided about their interpretation of Marxism and its applicability to Nicaraguan circumstances. ${ }^{8}$ What brought all these conflicting ideologies together was a pragmatic commitment to the revolution's success and then its survival.

A second contribution of the special issue is to examine international counterrevolutionary responses to the Nicaraguan Revolution. New histories of the Right - or Rights, as Sandra McGee Deutsch has encouraged historians to consider them-have been a major contribution to Cold War scholarship on 1986)

8. Donald C. Hodges, Intellectual Foundations of the Nicaraguan Revolution (Austin: University of Texas Press, 
Latin America in recent years. ${ }^{9}$ In conversation with such interventions, Molly Avery explores how a particular group of right-wing actors and networks in the Americas evolved and interacted with revolutionary developments in Nicaragua, shedding light on transnational anticommunist networks that spanned the Americas and extended around the globe. The actors that Avery focuses on, including the leaders of dictatorial regimes in Chile and Argentina, as well as extreme-right groups in Mexico, El Salvador, the United States, and Guatemala, were part of what she calls the Extreme Right, which was distinct from the wider Right "in its rejection of western-style democracy" and "preference for extra-judicial violence."

True, the Extreme Right often shared similar objectives and forums with other right-wing groups and even with some centrist parties that advocated for the overthrow of the Sandinista government and supported efforts to contain revolutionary tendencies in El Salvador and Guatemala. However, as Avery argues, there were sharp divisions and differences as to how to achieve these ends on the Right, just as there is now broad consensus when it comes to the heterogeneity of the Left. Ultimately, as she argues, Nicaragua was part of a much broader set of concerns relating to regional politics and global Cold War order that emerged in the mid 1970s. Responding to what was seen by anticommunist dictatorial regimes as the abdication of responsibility on the part of the United States to fight the Cold War, particularly during Jimmy Carter's administration, Chileans and Argentines worried about revolutionary insurgencies in El Salvador, Guatemala, and Nicaragua. When the FSLN triumphed, Avery writes, these fears became "reality" reaffirming and energizing Chilean and Argentine military training programs for Central Americans. Much like the United States from the early 1980s onward, but spearheading such operations and bypassing US initiatives to cultivate personal ties with key figures on the Extreme Right in Central America, Chile and Argentina's answer to the Nicaraguan Revolution was to launch unforgiving Cold War offensives in neighboring Central American states.

But of course, counterrevolution did not involve the Extreme Right or even other right-wing tendencies exclusively. Efforts to tame and contain the FSLN prior to

9. Sandra McGee Deutsch, Las Derechas: The Extreme Right in Argentina, Brazil, and Chile, 1890-1939 (Stanford: Stanford University Press, 1999); Kyle Burke, Revolutionaries for the Right: Anticommunist Internationalism and Paramilitary Warfare in the Cold War (Chapel Hill: University of North Carolina Press, 2018); Roberto García Ferreira and Arturo Taracena Arriola, eds., La guerra fría y el anticomunismo en Centroamérica (Guatemala City: FLACSO Guatemala, 2017); Aaron Coy Moulton, "Building Their Own Cold War in Their Own Backyard: The Transnational, International Conflicts in the Greater Caribbean Basin, 1944-1954," Cold War History 15: 2 (2015): 135-154; Julieta Carla Rostica, "La Confederación Anticomunista Latinoamericana. Las conexiones civiles y militares entre Guatemala y Argentina (1972-1980)," Desafios 30:1 (2018): 309-347; Kirsten Weld, "The Other Door: Spain and the Guatemalan Counter-Revolution, 1944-54," Journal of Latin American Studies 51:2 (May 2019): 307-331. 
1979 and thereafter comprised a far more complex multi-sided international response to the Nicaraguan Revolution. In this respect, Mateo Jarquín and Eline van Ommen show how Latin Americans and Europeans of different political tendencies, including Christian Democrats, centrists and social democrats, hoped to guide and moderate the FSLN through engagement, diplomacy, and financial incentives. As they attempted to do so, the experience of Cuba's turn to the east soon after 1959 loomed large as a warning of how not to deal with a revolutionary state. In the case of Europe, as Van Ommen shows, this had tangible results in prompting the FSLN to make significant concessions and ultimately accept holding of the 1990 elections that removed them from power.

The Nicaraguan Revolution had other direct international ramifications. For just as the Nicaraguan Revolution fostered greater coordination within transnational networks on both the Left and Right, it also promoted the growth of state-led collaboration when it came to the European Community's presence as a unified actor on the international stage and in multilateral diplomacy in Latin America. The Nicaraguan Revolution and responses to the FSLN regime, in other words, had effects on politics and developments beyond Nicaragua, affecting international diplomacy in Americas and Europe.

This brings us to the third contribution this special issue makes: namely, to illuminate the impact that the Nicaraguan Revolution had on international affairs and how we interpret them. Back in 2000, Tony Smith called for a "pericentric" perspective on the Cold War, one that appreciated the "role of [actors from] the periphery. . . as effective subjects" who shaped the international conflict by "expanding, intensifying and prolonging" it. ${ }^{10}$ In this respect, there are obvious points to make about the Nicaraguan Revolution's role in a new and intensified chapter of the Cold War in relation to the FSLN's revolutionary success and fervor or its part in initially resisting conditions for negotiation. As Avery's article shows, the intervention of the Argentine and Chilean dictatorships in Central America, meanwhile, helped militarize conflict, boosted the Extreme Right, and bypassed the United States. In fact, the impact of Carter's emphasis on human rights and détente made the United States far less directly relevant to the escalation of Cold War conflict between 1979 and 1981 than traditional Washington-centered narratives would have us believe.

As they engaged directly in the affairs of El Salvador, Guatemala, and Nicaragua, Southern Cone dictatorships also conceptualized Central and South America as belonging to "one and the same ideological struggle," provoking us to rethink

10. Tony Smith, "New Bottles for New Wine: A Pericentric Framework for the Study of the Cold War," Diplomatic History 24:4 (2000): 568-570. 
the separate ways in which the two subregions are so often studied in histories of the Cold War in Latin America. Rather than constituting different chapters of the conflict, separated by space and time, the stories of Southern Cone dictatorships and counterrevolutionary violence in Central America were intertwined, as Avery shows. Indeed, it seems that there were many Latin American identities that found regional commonality as a result of Cold War conflict. As the decade of the 1980s progressed, Jarquín argues, the Nicaraguan Revolution's impact on international affairs was to bring together a large diplomatic coalition representing different states with a vested interest in keeping further conflict from threatening the region. In their search for peace, they carved out a regional identity and space that strove to transcend the Cold War, which in turn came to underpin the inter-American system in the decades that followed. Direct responses to the conflict in Nicaragua, in short, paved the way for a new form of Latin American multilateralism in the 1990s and early 2000s.

These insights raise a number of broader issues that new international histories of Latin America and the Cold War might want to consider. If this special issue serves to take stock of a wave of new research and findings related to Nicaragua, it also serves as a springboard for future scholarship. Going forward, historians will question how localized ideological conflict has shaped and reshaped identities in the Americas, a point of particular interest in the contemporary context of social and political upheaval throughout Latin America. What, in other words, were the broader regional-and global-repercussions of revolutionary change and political or social crises in different parts of Latin America? And what did the revolution mean for national liberation movements and revolutionary states beyond the Americas, such as the Palestine Liberation Organization and the Vietnamese and Algerian governments?

Beyond this, it seems clear that we are only now beginning to probe the impact that the Cuban Revolution had in the region. ${ }^{11}$ Far more has to be understood with regard to the resonance, ramifications, and reverberations at state and non-state levels of other events that are typically framed as national. ${ }^{12}$ And, in this respect, the question of how Central America fits into conceptualizations of Latin America, as well as how it was understood by others in the Americas and beyond as similar or different, deserves more attention.

Emily Snyder's insights into the everyday history of diplomatic and cultural engagement also encourage us to explore international histories anew-not

11. Brown, Cuba's Revolutionary World; Renata Keller, Mexico's Cold War (Cambridge; New York: Cambridge University Press, 2017); Kruijt, Cuba and Revolutionary Latin America.

12. See for example Mark T. Hove, "The Arbenz Factor: Salvador Allende, U.S.-Chilean Relations, and the 1954 U.S. Intervention in Guatemala,” Diplomatic History 31:4 (2007): 623-663. 
only as the story of negotiations and diplomatic encounters between states, but also as the lived experiences of the individuals involved in the statecraft and policy-making that took place across borders. In this respect, the involvement of non-nationals in state- building is by no means the exclusive preserve of revolutionary states. Molly Avery's research on the Extreme Right in the Americas reminds us to look at broader networks of influence and power that operated simultaneously at state and non-state levels and to understand how they related to each other. While Eline van Ommen's research has served to globalize Nicaraguan affairs when it comes to Europe, there is also still much to learn about relations between Nicaragua-and the conflict to determine its future in the 1980s - and the wider world, in relation to both the Middle East, Asia and Africa, and the Soviet Bloc.

Last but by no means least, the question of memory struggles and legacies of the Nicaraguan Revolution also deserves far more attention in the future. ${ }^{13}$ The full implications of protests against Daniel Ortega's government that exploded in April 2018 on histories of Nicaragua's revolutionary past and the FSLN itself have yet to be determined, in part because the future balance of forces is still very much uncertain. It is clear that Nicaraguans are writing memoirs and opening up archival sources, but there are large gaps, particularly when it comes to documents relating to the inner workings of the FSLN's National Directorate and classified Cuban sources. For now, at least, the hope is that this special issue brings Nicaragua and Central America firmly into conversation with new Cold War histories of the Americas and beyond, raising questions and frameworks that will allow for future research.

London School of Economics

TANYA HARMER

London, United Kingdom

t.harmer@lse.ac.uk

University of Leeds

ELINE VAN OMMEN (D)

Leeds, United Kingdom

e.vanommen@leeds.ac.uk

13. For existing scholarship on the history of memory in Nicaragua, albeit published prior to recent protests in Nicaragua, see for example Hilary Francis, "iQue Se Rinda Tu Madre! Leonel Rugama and Nicaragua's Changing Politics of Memory," Journal of Latin American Cultural Studies 21:2 (2012): 235-252. More recent works reflecting on the present-day legacies and memories of the revolution include Alberto Cortés Ramos, Umanzor López Baltodano, and Ludwing Moncada Bellorin, eds., Anbelos de un muevo horizonte: aportes para una Nicaragua democrática (San José, Costa Rica: FLACSO, 2020); and Hilary Francis, ed., A Nicaraguan Exceptionalism? Debating the Legacy of the Sandinista Revolution (London: University of London Press, 2020). 